\title{
Peningkatan Keaktifan dan Prestasi Belajar Mahasiswa Pendidikan Biologi UAD Melalui Model Belajar Kelompok dan Media Pembelajaran Imitasi Persilangan pada Mata Kuliah Genetika
}

\author{
Trianik Widyaningrum dan Arief Abdillah Nurusman \\ Progam Studi Pendidikan Biologi, Universitas Ahmad Dahlan \\ Kampus III, Jl. Prof. Dr. Soepomo, SH, Yogyakarta, 55164 Indonesia \\ surat elektronik: trianikwidyaningrum@ymail.com
}

\begin{abstract}
ABSTRAK
Salah satu program studi di lingkungan Universitas Ahmad Dahlan adalah Program studi Pendidikan Biologi. Pada tahun 20II Program studi Pendidikan Biologi membuka Kelas baru yang berstandar Internasional dengan mahasiswa yang dibatasi yaitu 25 mahasiswa. Berdasar hasil belajar mahasiswa Pendidikan Biologi semester lima tahun ajaran 2010/20II pada mata kuliah genetika terlihat cukup memprihatinkan. Penelitian ini bertujuan untuk mengetahui peningkatan keaktifan dan prestasi belajar mahasiswa pendidikan biologi UAD khususnya pada kelas berstandar Internasional melalui model belajar kelompok dan media pembelajaran imitasi persilangan

Penelitian ini dilakukan di UAD kampus 3 Jl. Prof. Dr. Soepomo Janturan Yogyakarta mulai bulan September 2012 dengan menyesuaikan kalender akademik semester gasal tahun ajaran 2012/20I3. Subjek penelitian ini adalah mahasiswa pendidikan biologi UAD kelas berstandar Internasional semester lima yang berjumlah 25 mahasiswa yang dikelompokan menjadi 5 kelompok dan diberikan pembelajaran dengan model belajar kelompok dengan bantuan media pembelajaran imitasi persilangan, dengan melibatkan I dosen pengampu mata kuliah dan I dosen pengamat penelitian. Jenis penelitian ini adalah penelitian tindakan kelas yang dilakukan secara kolaboratif. Teknik Pengumpulan data yang dilakukan yaitu menggabungkan instrumen-instrumen penelitian yaitu data observasi keaktifan mahasiswa dan Hasil Belajar Mahasiswa

Berdasarkan hasil penelitian tentang perbaikan pembelajaran pada mata kuliah Genetika yang terdiri dari 2 siklus, serta melakukan pengamatan pada kegiatan tersebut, dapat dirumuskan kesimpulan bahwa prestasi belajar mahasiswa sebelum menggunakan variasi model pembelajaran dan media pembelajaran menunjukkan prestasi yang kurang memuaskan. Aktifitas mahasiswa selama proses pembelajaran genetika dengan metode ceramah, tanyajawab, penugasan, model belajar kelompok dan penggunaan media pembelajaran menunjukkan perubahan yang positif.
\end{abstract}

Kata kunci: keaktifan, prestasi belajar, belajar kelompok, media belajar, genetika

\section{Pendahuluan}

Salah satu program studi di lingkungan Universitas Ahmad Dahlan adalah Program studi Pendidikan Biologi. Jumlah mahasiswa pendidikan Biologi di UAD cenderung banyak ( \pm I50 mahasiswa perangkatan) dan sampai sekarang ini sudah mencapai sebelas angkatan. Pada tahun 20II Program studi Pendidikan Biologi membuka Kelas baru yang berstandar Internasional dengan mahasiswa yang dibatasi yaitu 25 mahasiswa. Rata-rata mahasiswa tersebut berasal dari Pulau Jawa, Sumatra, dan Kalimantan, sehingga kemampuan mahasiswa tersebut sangat beragam.

Setiap semester mahasiswa Pendidikan Biologi menempuh kurang lebih I8-24 SKS (tergantung dari indeks prestasi masing-masing mahasiswa). Setelah mahasiswa sampai pada semester lima mereka akan menempuh mata kuliah genetika yang merupakan salah satu mata kuliah keahlian bidang Biologi yang mempunyai bobot tiga SKS perkuliahan dan I SKS praktikum. Mata kuliah tersebut antara lain memuat teori-teori tentang pewarisan sifat keturunan, hukum Mendel, teori probabilitas penurunan sifat, Chi Square Test, Interaksi Gen, Rangkai Kelamin, Pindah Silang, dan Pembuatan Peta Kromosom. Dalam mata kuliah tersebut, mahasiswa dituntut untuk dapat memahami teori-teori tersebut dan juga memahami perhitungan probabilitas penurunan sifat, Chi Square Test, Interaksi Gen, Rangkai Kelamin, Pindah Silang, dan Pembuatan Peta Kromosom sehingga bila dilihat dari sifat mata kuliah tersebut, mahasiswa dituntut untuk dapat menghafal dan juga memahami langkah-langkah 
perhitungan dalam pewarisan sifat keturunan, Chi Square Test, Interaksi Gen, Rangkai Kelamin, Pindah Silang, dan Pembuatan Peta Kromosom.

Berdasar hasil belajar mahasiswa Pendidikan Biologi semester lima tahun ajaran 2010/20II pada mata kuliah genetika terlihat cukup memprihatinkan. Nilai hasil belajar mahasiswa tersebut tertinggi mencapai 8I,I5, rata-rata nilai 59,34, dan terendah mencapai 32,65, sehingga bila nilai tersebut ditransfer dalam bentuk huruf, banyak mahasiswa yang tidak lulus dalam mata kuliah tersebut. Bila dilihat dari prosentase keberhasilan mahasiswa tersebut terlihat hanya 37,37\% mahasiswa yang mendapat nilai A dan B, 24,24\% mendapatkan nilai C dan 38,39\% mendapatkan nilai D dan E.

Dalam proses belajar, pengajar memegang peranan yang sangat penting, sehingga selalu dituntut agar menggunakan model pembelajaran yang tepat supaya dapat mendukung siswa untuk belajar lebih giat lagi. Hal ini dengan sendirinya dapat meningkatkan nilai hasil belajar siswa yang akan dicapai. Begitu pula sebaliknya bila pengajar menggunakan model pembelajaran yang kurang tepat dengan kondisi siswa akan mengganggu dalam kegiatan belajarnya, sehingga nilai hasil belajar akan mengalami kemunduran (Hamalik, 2003) Model pembelajaran menurut Hamalik, (2003) antara lain Pembelajaran individual dan Pembelajaran Kelompok.

Selain model pembelajaran, media belajar juga mempengaruhi keberhasilan mahasiswa dalam pembelajarannya. Media secara harafiah diartikan sebagai perantara atau pengantar pesan dari pengirim ke penerima pesan. Gagne dalam Sadiman, A (2002) menyatakan bahwa media adalah berbagai jenis komponen dalam lingkungan siswa yang dapat menyajikan pesan serta merangsang siswa untuk belajar, seperti buku, film, kaset, gambar, dan lain sebagainya (Briggs dalam Arsyad, A , 2003). Media merupakan bentuk komunikasi baik tercetak maupun audiovisual serta peralatan yaitu yang dapat dimanipulasi, dilihat, didengar, dan dibaca (Anonim, 2000).

Hamalik (2003) juga menyampaikan bahwa ada faktor yang mempengaruhi keberhasilan dalam belajar antara lain kecerdasan, motivasi, konsentrasi, kesehatan jasmani,ambisi dan tekat, sedangkan Purwanto (2005 menyampaikan bahwa terdapat faktor yang mempengaruhi belajar dengan pendekatan seperti yang digambarkan pada Gambar I.

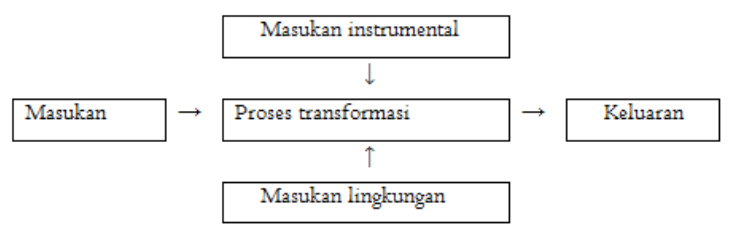

Gambar I. Skema proses transformasi belajar mengajar (Purwanto, 2005)
Untuk menyempurnakan keberhasilan dalam proses belajar dan mengajar, selain model pembelajaran dan media pembelajaran, juga diperlukan partisipasi aktif dari mahasiswa. Keaktifan Siswa dalam belajar Biologi dapat diartikan keaktifan siswa untuk memahami dan mendalami materi Biologi. Menurut Usman (2002) cara yang dapat digunakan pengajar untuk memperbaiki keterlibatan siswa adalah dengan meningkatkan persepsi siswa secara aktif dalam kegiatan belajar mengajar yang membuat respon yang aktif dari siswa, dan juga masa transisi antara kegiatan dalam mengajar hendaknya dilakukan secara cepat dan luwes. Siswa juga diberikan pengajaran yang jelas dan tepat sesuai dengan tujuan yang akan dicapai, serta diusahakan agar pengajaran dapat lebih memacu minat siswa.

Berdasar latar belakang tersebut, maka penting kiranya dilakukan penelitian untuk mengungkap sebabsebab ketidakberhasilan mahasiswa dalam belajar dan kemudian dilakukan upaya-upaya untuk menanggulangi kendala tersebut, antara lain melalui pengubahan model pembelajaran dan media belajar mahasiswa. Diharapkan nantinya dapat meningkatkan keberhasilan mahasiswa dalam menyerap dan memahami teori-teori pewarisan sifat dan juga langkah-langkah perhitungan dalam pewarisan sifat keturunan.

Penelitian ini bertujuan untuk mengetahui peningkatan keaktifan dan prestasi belajar mahasiswa pendidikan biologi UAD khususnya pada kelas berstandar Internasional melalui model belajar kelompok dan media pembelajaran imitasi persilangan.

\section{Metode Penelitian}

Penelitian ini dilakukan di UAD kampus 3 Jl. Prof. Dr. Soepomo Janturan Yogyakarta mulai bulan September 2012 dengan menyesuaikan kalender akademik semester gasal tahun ajaran 2012/2013. Subjek penelitian ini adalah mahasiswa pendidikan biologi UAD kelas berstandar Internasional semester lima yang berjumlah 25 mahasiswa yang dikelompokan menjadi 5 kelompok dan diberikan pembelajaran dengan model belajar kelompok dengan bantuan media pembelajaran imitasi persilangan, dengan melibatkan I dosen pengampu mata kuliah dan I dosen pengamat penelitian. Jenis penelitian ini adalah penelitian tindakan kelas yang dilakukan secara kolaboratif. Pihak yang melakukan tindakan adalah dosen pengampu sendiri sedangkan yang diminta melakukan pengamatan adalah dosen pendamping. Menurut Kemmis dan Taggard (Wiriaatmadja, 2005) ada beberapa tahapan dalam penelitian ini, yaitu:

I.Perencanaan (plan)

2. Tindakan (act)

3. Pengamatan (observe)

4. Refleksi (reflect)

Dalam penelitian ini dilakukan tiga siklus. Siklus dihentikan apabila kondisi kelas sudah stabil, mahasiswa sudah terbiasa dengan model pembelajaran kelompok 
dan media pembelajaran imitasi persilangan dan data yang ditampilkan di kelas sudah menunjukkan adanya peningkatan keaktifan dan prestasi belajar mahasiswa. Alur Penelitiannya adalah sebagai berikut:

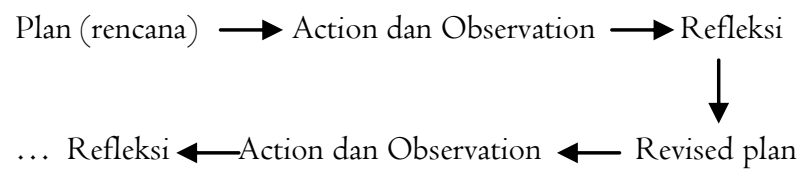

Gambar 2. Siklus PTK

\section{I.Perencanaan}

Pada tahap ini dosen pengampu menyiapkan silabus, Satuan Acara Perkuliahan, Handout, Lembar Kerja mahasiswa, Lembar observasi Keaktifan Mahasiswa, dan Lembar Observasi Pelaksanaan Pembelajaran.

2. Implementasi tindakan

Pelaksanaan tindakan pada siklus pertama dilakukan dengan tiga kali perkuliahan. Tahap perkuliahan diberikan dosen dengan menggunakan model belajar kelompok dan Media pembelajaran Imitasi persilangan. Materi kuliah yang diberikan adalah Mendelisme, Probabilitas dalam persilangan, dan Interaksi Gen.

Adapun tindakan yang dilakukan pada setiap siklus adalah:

a. Pendahuluan

Dosen menyampaikan perkuliahan dengan memberikan apersepsi dan motivasi kepada mahasiswa

b. Kegiatan Inti

I) Dosen memberikan perkuliahan dengan metode ceramah dan tanya jawab dibantu media imitasi persilangan

2) Mahasiswa belajar dalam kelompok

3) Setelah perkuliahan dosen memberikan tugas mengerjakan soal-soal yang ada dalam diktat kuliah genetika

4) Mahasiswa menyelesaiakn tugas secara berkelompok

5) Mahasiswa mengerjakan tugas di white board dipandu dosen pengampu dan dosen pendamping

c. Penutup

Dosen memberikan penguatan terhadap jawaban mahasiswa

\section{Observasi dan Interprestasi}

Dilakukan selama proses perkuliahan dengan menggunakan lembar observasi yang telah disediakan dan mencatat kejadian-kejadian yang tidak terdapat pada lembar observasi dengan membuat catatan lapangan. Hal-hal yang diamati selama perkuliahan adalah kegiatan pembelajaran dan aktivitas dosen maupun mahasiswa selama pelaksanaan perkuliahan.

\section{Analisis dan Refleksi}

Pada tahap ini dosen pendamping melakukan evaluasi dari pelaksanaan tindakan pada siklus I yang digunakan sebagai bahan pertimbangan perencanaan pembelajaran pada siklus berikutnya. Jika hasil yang diharapkan belum tercapai maka dilakukan perbaikan yang dilaksanakan pada siklus kedua dan seterusnya.

5. Siklus Tindakan

Rencana Tindakan siklus II dimaksudkan sebagai hasil refleksi dan perbaikan terhadap pelaksanaan perkuliahan pada siklus I. Kegiatan pada siklus III dimaksudkan sebagai hasil refleksi dan perbaikan terhadap perkuliahan pada siklus II. Tahapan tindakan pada siklus II dan III mengikuti tahapan pada siklus I.

\section{Indikator Pencapaian}

Indikator capaian pada penelitian ini yaitu meningkatnya keaktifan dan prestasi belajar mahasiswa Pendidikan Biologi UAD, khususnya kelas berstandar Internasional. Peningkatan keaktifan belajar diamati saat proses perkuliahan berlangsung. Peningkatan prestasi belajar mahasiswa dilihat dari hasil tes mahasiswa hasil perkuliahan denghan menerapkan model belajar kelompok dan media imitasi persilangan dengan nilai ketuntasan 60.

Dalam Penelitian ini digunakan dua lembar observasi, yaitu lembar observasi keaktifan mahasiswa dan lembar observasi pelaksanaan pembelajaran menggunakan model belajar kelompok dan media imitasi persilangan.

Teknik analisis data yang dilakukan meliputi:

\section{Data Observasi Keaktifan Mahasiswa}

Data hasil observasi dianalisis untuk mengetahui keaktifan mahasiswa yang berpedoman pada lembar observasi keaktifan mahasiswa. Penilaian dilihat dari hasil skor pada lembar observasi yang digunakan. Persentase diperoleh dari skor pada lembar observasi dikualifikasikan untuk menentukan besarnya keaktifan mahasiswa selama proses perkuliahan berlangsung. Untuk setiap siklus, persentase diperoleh dari rata-rata persentase keaktifan mahasiswa pada setiap pertemuan. Hasil data observasi tersebut dianalisis berdasarkan kriteria pada Tabel I.

Tabel I. Kriteria Keaktifan Mahasiswa

\begin{tabular}{ll} 
Persentase & Kriteria \\
\hline $75 \%-100 \%$ & Sangat tinggi \\
\hline $50 \%-74,9 \%$ & Tinggi \\
\hline $25 \%-49,9 \%$ & Sedang \\
\hline $0 \%-24,9 \%$ & Rendah \\
\hline
\end{tabular}

Cara menghitung persentase keaktifan mahasiwa berdasar hasil observasi untuk tiap pertemuan adalah sebagai berikut: 
Persentase $=$ Skor keseluruhan yang diperoleh kelompok $\times 100 \%$ Jumlah kelompok $\mathrm{x}$ skor maksimum

(Sugiono, 200I)

\section{Analisis Belajar Mahasiswa}

Hasil tes mahasiswa dianalisis untuk menentukan peningkatan ketuntasan mahasiswa, nilai individu, dan skor kelompok.

a. Peningkatan ketuntasan mengikuti ketentuan bahwa mahasiswa dinyatakan lulus dalam setiap tes jika nilai yang diperoleh $\geq 60$ dengan nilai maksimum IOO, dengan perhitungan sebagai berikut:

Persen (\%) Ketuntasan $=$ Jumlah siswa tuntas $\quad \times 100 \%$ Jumlah Siswa

b. Peningkatan prestasi belajar mahasiswa juga dilihat dari hasil belajar jangka pendeknya dengan kenaikan nilai rata-rata tes tiap siklusnya. Dari data perolehan skor tiap tes, rata-rata nilai mahasiswa dengan menggunakan perhitungan sebagai berikut:

$\mathrm{X}=\sum \mathrm{X}_{i}$

$\mathrm{i}=25 ; X=\mathrm{i} / \mathrm{n}$

dengan $\mathrm{x}=$ nilai siswa dan $\mathrm{n}=$ jumlah siswa

(Sugiyono, 200I)

\section{Hasil dan Pembahasan}

Tindakan awal yang dilakukan pada penelitian ini adalah menggunakan refleksi terhadap metode pembelajaran yang telah dilakukan selama ini. Adapun tujuannya adalah untuk mengetahui kemampuan mahasiswa dalam menyelesaikan soal tentang mendelisme dalam mata kuliah Genetika. Selain itu, juga memberikan pemahaman tentang pentingnya menentukan suatu metode pembelajaran yang tepat agar tercapai tujuan pembelajaran yang telah ditetapkan. Dari hasil tindakan awal tersebut, dapat dinyatakan bahwa ketidakberhasilan mahasiswa serta ketidakseriusan mahasiswa dalam mengikuti mata kuliah genetika, selain disebabkan oleh kurangnya kemampuan mahasiswa dalam menangkap materi yang disajikan dosen pengampu, juga disebabkan oleh kurangnya metode belajar kelompok dalam penyelesaian soal-soal pada materi genetika.

\section{Materi Mendelisme, Interaksi Gen dan Pemahaman Hukum Chi Square Test pada Tindakan Pertama ( siklus I)}

Berdasarkan temuan masalah pada pembelajaran mata kuliah genetika pada mahasiswa PGBI semester $\mathrm{V}$ pada Materi tentang Mendelisme, Interaksi Gen dan Pemahaman Hukum Chi Square Test dengan jumlah mahsiswa 25 siswa. Maka diadakan perbaikan siklus I yang dilaksanakan pada tanggal 24 November 20I2, I Oktober 2012, serta 8 Oktober 2012. Pada tahap ini dosen merumuskan skenario pembelajaran dengan memberikan penjelasan materi tentang Mendelisme,
Interaksi Gen dan Pemahaman Hukum Chi Square Test serta contoh pengerjaan soal tentang materi Mendelisme, Interaksi gen, dan Hukum Chi Square Test.

Memasuki kegiatan inti dosen menjelaskan materi tersebut dengan bantuan media pembelajaran imitasi persilangan dan imitasi interaksi gen sambil memberikan banyak contoh cara menyelesaikan soal tentang materi Mendelisme, Interaksi gen, dan Hukum Chi Square Test tersebut. Setelah dianggap paham dan mengerti, dosen memberikan soal kepada mahasiswa tentang materi Mendelisme, Interaksi gen, dan Hukum Chi Square Test dan mahasiswa secara berkelompok mengerjakan soal tersebut. Kemudian dosen memberikan evaluasi untuk mengukur keberhasilan mengajar mahasiswa (soal terlampir). Dari tindakan siklus pertama didapat hasil evaluasi tersebut serta hasil observasi tentang hasil kinerja dosen.

Dari siklus I didapat hasil 8 mahasiswa mendapat nilai di bawah 60, dan 17 mahasiswa mendapat nilai di atas 60. Dengan hasil seperti pada Tabel I.

Berdasar data tersebut nilai ketuntasan mahasiswa adalah $17 / 25 \times 100 \%=68 \%$, dengan nilai rata-rata 67,32. Berdasarkan hasil observasi terhadap keaktifan mahasiswa (lembar observasi) terlihat masih banyak mahasiswa yang belum aktif dalam kerja kelompok dalam mengerjakan soal-soal latihan saat perkuliahan berlangsung tersaji pada Tabel 2 .

Tabel 2. Hasil Evaluasi Pembelajaran Genetika pada Siklus I

\begin{tabular}{|c|c|c|}
\hline $\mathrm{Nim}$ & Nama Mahasiswa & Nilai Siklus I \\
\hline $\mathrm{IIa0800I}$ & Winda Purnama Sari & $9 \mathrm{I}$ \\
\hline IIa08002 & Aprilia Pangestika & 37 \\
\hline $\mathrm{IIa08003}$ & Yulisna Hawarya & 50 \\
\hline II a08004 & Rizkyana Cindylita Aprisiwi & 84 \\
\hline $\mathrm{IIa08005}$ & Anna Atiqa Priyadi & 73 \\
\hline I Ia08006 & Ana Dian Rahayu & 73 \\
\hline II a08007 & Safika Rahmawati & 80 \\
\hline $\mathrm{IIa08008}$ & Titin Solikhah & 84 \\
\hline I Ia08009 & Utami Khoerunnisa & 73 \\
\hline IIa080I0 & Parni Astuti & 67 \\
\hline I Ia080I I & Galuh Alif Fahmi Rizki & 77 \\
\hline I Ia080I2 & Riza Nurmawati & 77 \\
\hline IIa080I3 & Haris Setiawan & 82 \\
\hline $\mathrm{IIa080I4}$ & Fajar Nur Cahyani & 89 \\
\hline IIa080I5 & Angga Dwi Prasetyo & 63 \\
\hline IIa080I6 & Devinta Dwi Marviana & 47 \\
\hline IIa080I7 & Tuti Eka Wahyuni & 56 \\
\hline IIa080I8 & Leni Apriliana Sari & $9 \mathrm{I}$ \\
\hline IIa080I9 & Vintaka Ratih & 69 \\
\hline I Ia08020 & Persita Pupung Hariadi & 54 \\
\hline I Ia0802I & Isti Ariningsih & 48 \\
\hline $\mathrm{IIa08022}$ & Yuningsih & $7 \mathrm{I}$ \\
\hline I Ia08023 & Nur Khamidah & 22 \\
\hline I Ia08024 & Nur Laely Fitriani & 43 \\
\hline $\mathrm{IIa08025}$ & Nesya Arantika Dewi & 82 \\
\hline & Jumlah Nilai & 1683 \\
\hline & Nilai Rata-Rata & 67,32 \\
\hline
\end{tabular}

\section{Refleksi Siklus I}

Pembelajaran Genetika pada mahasiswa PGBI semester $\mathrm{V}$ dengan metode belajar kelompok dan 
bantuan media pembelajaran dapat memberikan peningkatan kepada mahasiswa terhadap materi pembelajaran yang dipelajari. Dari analisis data didapat rata-rata nilai dan hasil observasi yang dapat ditafsirkan sebagai berikut :

Pelajaran Genetika hasil rata-rata evaluasi pada siklus I terlihat baru 68\% mahasiswa yang tuntas dengan nilai rata-rata dan nilai rata-rata 67,32. Pada siklus I tersebut, pada umumnya proses pembelajaran terlihat lancar dan mahasiswa banyak memperhatikan pada saat dosen membahas tentang soal-soal latihan yang diberikan, serta mahasiswa terlihat aktif mengerjakan soal secara berkelompok, tetapi masih ada 8 mahasiswa yang belum tuntas, maka dosen dan observer sepakat untuk mengadakan perbaikan lagi pada siklus II agar semua siswa mendapat nilai di atas 60 .

\section{Materi Rangkai Kelamin, Pautan dan Pindah silang, serta pembuatan Peta Kromosom pada Tindakan Kedua (Siklus II)}

Berdasari tampilan siklus I pada pembelajaran Genetika terhadap mahasiswa PGBI semester $\mathrm{V}$ yang berjumlah 25 mahasiswa, kemudian dilakukan tindakan perbaikan yang diawali dengan dosen merumuskan skenario pembelajaran berkaitan dengan materi Rangkai Kelamin, Pautan dan Pindah silang, serta pembuatan Peta Kromosom. Memasuki kegiatan inti guru menjelaskan materi tersebut yang kemudian dilanjutkan dengan pembahasan soal berkaitan dengan materi tersebut. Kemudian dosen memberikan latihan soal berkaitan dengan materi tersebut dan memerintahkan mahasiswa untuk mengerjakan secara berkelompok. Setelah dianggap paham dan mengerti kemudian dosen memberikan evaluasi terhadap materi pembelajaran tersebut untuk mengukur keberhasilan mengajar mahasiswa juga sebagai umpan balik dan perbaikan.

Dari siklus II didapat hasil evaluasi terdapat peningkatan dari hasil evaluasi pada siklus I, dan diperoleh hasil semua mahasiswa mendapat nilai di atas 60 , meskipun ada 2 orang mahasiswa yang mendapatkan nilai 62 , tetapi bila dilihat dari persentase keberhasilan I00 \% mahasiswa tersebut sudah tuntas dengan hasil selengkapnya pada Tabel 3 berikut ini:

Tabel 3. Hasil Evaluasi Pembelajaran Genetika pada Siklus II

\begin{tabular}{|c|l|c|}
\hline Nim & \multicolumn{1}{|c|}{ Nama Mahasiswa } & $\begin{array}{c}\text { Nilai Siklus } \\
\text { II }\end{array}$ \\
\hline I Ia0800I & Winda Purnama Sari & 87 \\
\hline I Ia08002 & Aprilia Pangestika & 62 \\
\hline I Ia08003 & Yulisna Hawarya & 79 \\
\hline I Ia08004 & Rizkyana Cindylita Aprisiwi & 7 I \\
\hline IIa08005 & Anna Atiqa Priyadi & $8 \mathrm{I}$ \\
\hline I Ia08006 & Ana Dian Rahayu & 87 \\
\hline IIa08007 & Safika Rahmawati & 86 \\
\hline IIa08008 & Titin Solikhah & 88 \\
\hline I Ia08009 & Utami Khoerunnisa & 80 \\
\hline IIa080I0 & Parni Astuti & 88 \\
\hline I Ia080II & Galuh Alif Fahmi Rizki & 62 \\
\hline
\end{tabular}

\begin{tabular}{|c|l|c|}
\hline Nim & \multicolumn{1}{|c|}{ Nama Mahasiswa } & $\begin{array}{c}\text { Nilai Siklus } \\
\text { II }\end{array}$ \\
\hline IIa080I2 & Riza Nurmawati & II \\
\hline IIa080I3 & Haris Setiawan & $8 \mathrm{I}$ \\
\hline IIa080I4 & Fajar Nur Cahyani & 94 \\
\hline IIa080I5 & Angga Dwi Prasetyo & 94 \\
\hline IIa080I6 & Devinta Dwi Marviana & $8 \mathrm{I}$ \\
\hline IIa080I7 & Tuti Eka Wahyuni & $7 \mathrm{I}$ \\
\hline IIa080I8 & Leni Apriliana Sari & 92 \\
\hline IIa080I9 & Vintaka Ratih & 90 \\
\hline IIa08020 & Persita Pupung Hariadi & 82 \\
\hline IIa0802I & Isti Ariningsih & 93 \\
\hline IIa08022 & Yuningsih & 67 \\
\hline IIa08023 & Nur Khamidah & 85 \\
\hline IIa08024 & Nur Laely Fitriani & 75 \\
\hline IIa08025 & Nesya Arantika Dewi & 77 \\
\hline & Jumlah Nilai & 2024 \\
\hline & Nilai Rata-Rata & 80,96 \\
\hline
\end{tabular}

Berdasar hasil observasi terhadap keaktifan belajar mahasiswa terlihat terdapat peningkatan karena hampir semua mahasiswa aktif bertanya dan mengerjakan soal secara berkelompok.

\section{Refleksi Siklus II}

Pada tampilan siklus II proses pembelajaran meningkat disebabkan oleh dosen dapat memahami kendala yang dihadapinya pada tampilan sebelumnya. Mahasiswa lebih aktif dan kreatif dalam menyelesaikan soal-soal. Selain adanya peningkatan keaktifan juga terbukti pada pencapaian nilai rata-rata hasil evaluasi pada siklus kedua diperoleh hasil 100\% mahasiswa mencapai nilai tuntas dengan nilai rata-rata 80,96.

Pembahasan terhadap hasil penelitian dengan cara menyajikan beberapa penemuan siklus yang penting dan berkaitan dengan faktor penelitian. Pada pembahasan ini akan dibahas mengenai penerapan penggunaan variasi model pembelajaran dan media pembelajaran pada mata kuliah Genetika.

Pada pembelajaran siklus I dan siklus II, penerapan variasi model pembelajaran yaitu selain ceramah, tanyajawab, penugasan, dan belajar kelompok serta variasi media pembelajaran dengan menggunakan imitasi persilangan dan imitasi interaksi gen yang mempunyai kelebihan:

a) Proses pembelajaran menjadi lebih menarik dan interaktif

b)Mengubah peran dosen ke arah yang lebih positif dan produktif

c) Mahasiswa lebih mengerti dan memahami materi tersebut, serta lebih aktif dalam mengikuti perkuliahan Genetika

\section{Simpulan}

Berdasarkan hasil penelitian tentang perbaikan pembelajaran pada mata kuliah Genetika yang terdiri dari 2 siklus, serta melakukan pengamatan pada kegiatan tersebut, dapat disimpulankan: 
I. Prestasi belajar mahasiswa sebelum menggunakan variasi model pembelajaran dan media pembelajaran menunjukan prestasi yang kurang memuaskan.

2. Aktifitas mahasiswa selama proses pembelajaran genetika dengan metode ceramah, tanyajawab, penugasan, model belajar kelompok dan penggunaan media pembelajaran menunjukan perubahan yang positif. Terbukti dengan keaktifan dan keterlibatan dari mahasiswa secara baik.

3. Pada pembelajaran mata kuliah genetika, dosen harus banyak memberikan contoh pengerjaan soal yang bervariasi dan mengikut sertakan mahasiswa dalam proses penyelesaian soal-soal tersebut secara berkelompok dan menunjuk perwakilan dari kelompok tersebut untuk mengerjakan soal di depan kelas dengan bimbingan dosen pengampu.

4. Prestasi belajar mahasiswa pada materi Mendelisme, interaksi gen, penerapan hukum Chi Square Test, rangkai kelamin, pautan dan pindah silang serta pembuatan peta kromosom menunjukan hasil yang memuaskan. Prestasi ini terlihat dari hasil evaluasi siswa, terlihat nilai mahasiswa sudah di atas 60 .

5. Dosen dapat menemukan berbagai metode pembelajaran yang menarik pada mata kuliah genetika, dengan tujuan agar mahasiswa lebih interaktif dalam pembelajaran genetika di masa sekarang dan yang akan datang.

\section{Daftar Pustaka}

Anonim. 2000. Media Pembelajaran. Jakarta: PT Garfindo. Persada.

Arsyad, Azhar. 2002. Media Pendidikan. Jakarta Raja Grafindo Persada.

Gagne,R.M. I970. Instuctional Technology. Lawrence Erlmaum Associaties. Hillsdok.

Gerlach Vb and Ely Dp. 2003. Teaching and Media A Systematic Approach. Printice-hall. Englewood Cliffs.

Hamalik, Oemar, 2003. Metode Belajar dan Kesulitankesulitan Belajar. Bandung: Tarsito.

Rochiati Wiriatmadja. 2005. Metode Penelitian Tindakan Kelas. Bandung: Remaja Rosdakarya.

Purwanto, 2005. Psikologi Pendidikan. Jakarta: Andi Offset.

Rusyam,T, Kusdinar, Arifin, 2003. Pendidikan dalam Proses Belajar Mengajar. Bandung: PT.Remaja Rosdakarya.

Sadiman, Arif S. 2002. Media Pendidikan, Pengetian, Pengembangan dan Pemanfaatan. Jakarta: Raja Grafindo Persada .

Sugiyono. 200I. Metode Penelitian Administrasi. Bandung: Alfabeta.

Usman. 2002. Menjadi Guru Profesional. Bandung: Remaja Rosdakarya. 